\title{
Identifikasi Potensi Ciri-Ciri Wirausaha Dengan Model Anggadiredja Dan Djajamihardja Pada Mahasiswa Universitas Gunung Rinjani
}

\author{
Siti Reuni Inayati ${ }^{1}$, Lalu Rizal Ihwandi ${ }^{2}$ \\ ${ }^{1,2}$ Prodi Akuntansi FE Universitas Gunung Rinjani \\ Email: reuniku09@gmail.com,rizal71ihwandi@gmail.com
}

Received: 08 November, 2020; Accepted: 24 November 2020; Published: 15 Desember, 2020

\begin{abstract}
Abstrak
Penelitian ini bertujuan untuk Mengetahui Seberapa Tinggi Potensi Ciri-ciri Wirausaha Mahasiswa Universitas Gunung Rinjani dengan Model Anggadiredja dan Djajamihardja. Jenis penelitian ini adalah penelitian kuantitatif yang bersifat statistik deskriptif. Data dikumpulkan dengan menggunakan kuisioner dengan jumlah responden sebanyak 150 orang. Ada 4 tahap yang dilakukan dalam penelitian ini, pada tahap pertama pembuatan daftar 96 pernyataan mengenai 12 ciri-ciri wiraswasta menurut Anggadiredja dan Djajamihardja (1991). Tahap kedua, responden cukup menjawab atau memberikan pendapat terhadap 96 pernyataan dalam tabel. Selanjutnya tahap ketiga dan keempat yaitu penilaian ciri-ciri wirausaha dan mengetahui tingkat potensi yang dimiliki responden dengan menggunakan teknik analisis deskriptif. Hasil penelitian menunjukkan bahwa Berdasarkan hasil kuisioner dari 150 orang responden, diperoleh nilai rata-rata untuk ciri pertama yaitu sebesar 24,7, ciri kedua nilai rata-ratanya yaitu 24,6, ciri ketiga nilai rata-ratanya 24,7 , ciri keempat nilai rata-rata sebesar 25,4 , ciri kelima nilai rata-ratanya 25,37 , ciri keenam nilai rata-ratanya 25,5 , ciri ketujuh diperoleh nilai rata-rata 24,75 , ciri kedelapan diperoleh nilai rata-rata 24,6 , ciri kesembilan nilai rata-ratanya 24,2 , ciri kesepuluh nilai rata-ratanya 24,45 , ciri kesebelas nilai rata-ratanya 25,1 dan ciri kedua belas nilai rata-ratanya sebesar 25,1. Sehingga demikian dapat disimpulkan bahwa potensi ciri-ciri wirausaha yang dimiliki masing-masing responden berada pada kategori sedang karena memiliki rentang nilai antara 17-31.
\end{abstract}

Kata kunci : Wirausaha; Model Anggadiredja dan Djajamihardja; Ciri-ciri wirausaha

\begin{abstract}
This study aims to determine how high the potential for entrepreneurial characteristics of Gunung Rinjani University students using the Anggadiredja and Djajamihardja models. This type of research is a quantitative research which is descriptive statistics. Data were collected using a questionnaire with a total of 150 respondents. There are 4 stages in this research, in the first stage making a list of 96 statements regarding 12 characteristics of entrepreneurship according to Anggadiredja and Djajamihardja (1991). The second stage, respondents simply answer or provide an opinion on the 96 statements in the table. Furthermore, the third and fourth stages, namely the assessment of entrepreneurial characteristics and knowing the potential level of respondents using descriptive analysis.
\end{abstract}


Research results show that, Based on the results of the questionnaire from 150 respondents, the average value for the first characteristic is 24.7 , the second characteristic is 24.6 , the third characteristic is 24.7 , the fourth feature is the average value is 24.7. 25.4, the fifth feature has an average value of 25.37, the sixth feature has an average value of 25.5, the seventh characteristic has an average value of 24.75 , the eighth characteristic is obtained an average value of 24.6, the ninth feature has an average value -the average value is 24.2 , the average value of the ten characteristics is 24.45 , the average value of the eleventh characteristic is 25.1 and the average value of the twelfth feature is 25.1. So it can be concluded that the potential for entrepreneurial characteristics of each respondent is in the medium category because it has a value range between 17-31

Keywords: entrepreneurship; Anggadiredja and Djajamihardja models; Entrepreneurial characteristics

\section{PENDAHULUAN}

Keberhasilan pembangunan dalam bidang ekonomi ditentukan oleh kemampuan pelaku-pelaku pembangunan baik pemerintah pusat maupun pemerintah daerah sebagai pengambil kebijakan (pengaturan) ekonomi, masyarakat sebagai pengguna dan pekerja sementara para pelaku ekonomi (wirausaha) sebagai penggerak produksi, distribusi dan konsumsi. Pembangunan akan lebih berhasil jika ditunjang oleh wirausaha yang mampu membuka lapangan kerja, karena kemampuan pemerintah sangat terbatas. Pemerintah tidak akan mampu menggarap semua aspek pembangunan, oleh sebab itu wirausaha merupakan potensi pembangunan, baik dalam jumlah maupun dalam mutu wirausaha itu sendiri.

Semakin maju suatu negara dan semakin meningkatnya tingkat pendidikan dapat dilihat dari semakin banyaknya jumlah lulusan dari suatu perguruan tinggi. Sayangnya, tingginya tingkat kelulusan ini juga berbanding lurus dengan tingginya tingkat pengangguran. Tingginya tingkat pengangguran lulusan perguruan tinggi ini disebabkan adanya ketimpangan antara profil lulusan universitas dengan kualifikasi tenaga kerja siap pakai yang dibutuhkan oleh perusahaan (Kompas, 2016). Keterbatasan terserapnya tamatan perguruan tinggi di sektor pemerintahan mengakibatkan beralihnya atensi pada kesempatan bekerja di sektor swasta, akan tetapi beratnya ketentuan yang dipersyaratkan kadangkala menjadikan kesempatan untuk bekerja di sektor swasta pun menjadi terbatas. Sehingga peluang yang ada dan masih sangat besar yaitu dengan berwirausaha (Suwena, 2015). 
Dalam rangka meningkatkan kemampuan diri sebagai seorang wirausahawan yang berpotensi, seseorang perlu mengenal potensi diri sendiri atau orang lain untuk dapat mengetahui apakah seseorang itu siap atau belum didalam melakukan wiraswasta suatu jenis usaha tertentu. Sebagaimana dalam penelitian yang dilakukan Suwena (2015) bahwa pengetahuan yang hendaknya dipunyai oleh wirausahawan ialah intinya kenali diri sendiri, area, bidang usaha yang dimasuki, ketahui apa yang wajib dicoba, serta memahami proses serta sistem yang ditangani, apa yang dicapai, bagaimana metode mencapainya, serta akibat, dan metode mengatasi akibat ini. Dengan kata lain, seseorang wirausaha perlu mempunyai pengetahuan serta keahlian yang layak untuk bisa menunjukan dirinya, mendapatkan kesempatan usaha, menyusun konsep usaha, membuat perencanaan, masuk pasar serta beroperasi dalam (organisasi/ sendiri).

Dalam menggali potensi jiwa kewirausahaan mahasiswa dilihat dari bermacam indikator nilai- nilai tertentu yang membuktikan jika tingkatan kemampuan jiwa kewirausahaan mahasiswa terletak pada kategori tengah/ cukup tetapi cenderung besar (Harfandi, 2014). Sebagian watak hakiki jiwa kewirausahaan yang kuat (bagi anggapan mahasiswa) merupakan watak yang ingin bekerja keras, penampilan yang baik, percaya, pandai membuat keputusan, ingin menambahkan ilmu pengetahuan, tekad untuk maju, pandai berinteraksi, berkomitmen terhadap tugas, bertanggung jawab, minat kewirausahaan, kesempatan meraih obsesi, energik, motivasi untuk unggul, berorientasi ke masa depan, ingin belajar dari kegagalan. Sebaliknya sebagian watak yang tidak kuat merupakan keahlian bekerja sama dengan orang lain, mau mendapatkan balikan selekasnya, kreatif serta fleksibel, keahlian mengelola serta toleransi/ suka memberi. (Rumijati, 2010) juga menyatakan bahwa potensi kewirausahaan mahasiswa mempunyai pengaruh yang paling kuat terhadap minat berwirausaha, sehingga perlu upaya untuk menumbuhkan potensi kewirausahaan yang dimiliki mahasiswa. Peningkatan dan pengembangan potensi kewirausahaan mahasiswa dapat memberikan kontribusi positif pada pelaksanaan operasional dan kesuksesan kewirausahaan mahasiswa itu sendiri (Satrya, 2015) 
Dalam rangka mengembangkan diri sebagai seorang wirausahawan yang potensial, seseorang perlu mengenal potensi diri sendiri atau orang lain untuk dapat mengetahui apakah seseorang itu siap atau belum dalam melakukan wiraswasta suatu jenis usaha tertentu. Sedikit tidaknya dengan mengidentifikasi kemampuan diri yang terdapat dalam diri mahasiswa bisa memberikan cerminan tentang seberapa jauh seorang tersebut merasa dirinya perlu memperbaiki diri serta belajar supaya lebih baik lagi. Memahami diri sendiri berarti mendapatkan pengetahuan tentang keseluruhan diri yang tepat, menyadari kelebihan/ keunggulan yang dipunyai ataupun kekurangan/ kelemahan yang terdapat pada diri sendiri yang nantinya dijadikan sebagai sumber kesuksesan dalam berwirausaha.

Mengenal potensi diri sendiri atau orang lain untuk bertindak sebagai seorang wiraswasta adalah penting, agar dapat mengetahui apakah seseorang itu siap atau belum dalam melakukan wiraswasta suatu jenis usaha tertentu. Model pengenalan potensi kewiraswastaan seseorang yang memiliki dua belas ciri-ciri tersebut diatas dengan tingkatan tertentu dengan cara menggambarkan beberapa pemikiran dan tindakannya dengan sembilan puluh enam pernyataan-pernyataan dapat digambarkan dalam beberapa alur (tahapan) sebagai berikut:

Gambar 1. Model Pengenalan Potensi Wiraswasta

Tahap 1

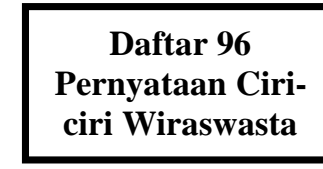

Tahap 2

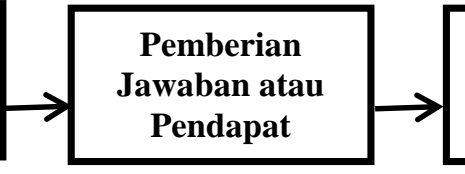

Tahap 3

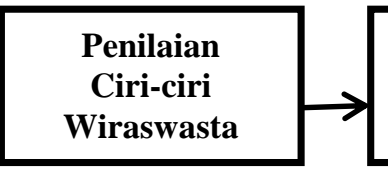

Tahap 4

Sumber: Anggadiredja dan Djajamihardja (1991)

Keterangan:

Tahap 1:

Pembuatan daftar 96 pernyataan mengenai 12 ciri-ciri wiraswasta menurut Anggadiredja dan Djajamihardja (1991)

Tahap 2:

Seseorang atau calon wiraswasta cukup menjawab atau memberikan pendapat terhadap 96 pernyataan dalam tabel dengan kode sebagai berikut: sangat setuju 
(SS), setuju (S), tidak yakin (TY), tidak setuju (TS), dan sangat tidak setuju (STS) pada kolom jawaban.

Tahap 3:

Cara penilaiannya sebagai berikut: nomor 1-96 pernyataan dalam tabel berkaitan dengan ke 12 ciri-ciri seorang wiraswasta dan ditempatkan dalam dua kolom, diberi penilaian dengan cara yang berbeda, yaitu kolom 1 nilai menurun (Kode $\mathrm{SS}=$ nilai $5, \mathrm{~S}=4, \mathrm{TY}=3$, TS $=2$, dan $\mathrm{STS}=1$ ) dan kolom 2 nilai meningkat (Kode $\mathrm{SS}=$ nilai $1, \mathrm{~S}=2, \mathrm{TY}=3, \mathrm{TS}=4$, dan $\mathrm{STS}=5$ ). Selanjutnya untuk setiap ciri (dari 12 ciri-ciri) dalam 12 baris, tiap nilai dari kedua kolom tadi dijumlahkan

Tahap 4:

Nilai total untuk tiap-tiap baris menunjukkan tingkat potensi ciri-ciri wiraswasta dengan kriteria sebagai berikut: nilai $32-40=$ tinggi, nilai $17-31=$ sedang dan nilai $8-16=$ rendah. Selanjutnya digambarkan dalam bentuk matrik sehingga dapat memberi gambaran pada kita mengenai tingkat potensi ciri-ciri wiraswasta yang dimiliki seseorang.

\section{METODE}

Jenis penelitian yang digunakan dalam penelitian ini adalah termasuk metode penelitian kuantitatif dimana untuk menganalisis datanya menggunakan metode statistik deskriptif. Metode statistik deskriptif adalah statistik yang digunakan untuk menganalisis data dengan cara mendeskripsikan atau menggambarkan data yang telah terkumpul sebagaimana adanya tanpa bermaksud membuat kesimpulan yang berlaku untuk umum atau generalisasi (Sugiyono, 2012). Alasan peneliti memilih metode penelitian tersebut yakni karena hal ini sangat berkaitan dengan judul maupun rumusan masalah yang telah diungkapkan peneliti pada bagian pendahuluan, dimana penelitian ini hanya ingin mengetahui seberapa tinggi potensi ciri-ciri wirausaha yang dimiliki oleh Mahasiswa Universitas Gunung Rinjani dengan mendeskripsikan data sampel dan tidak ingin membuat kesimpulan yang berlaku untuk populasi dimana sampel diambil. Potensi yang dimiliki tinggi apabila rentang nilai antara 32 - 40, potensi sedang dengan 
rentang nilai antara 17-31 dan potensi rendah dengan rentang nilai antara 8-16 (D. Anggadiredja, 1991)

Penelitian ini dilakukan pada kampus Universitas Gunung Rinjani Kabupaten Lombok Timur Provinsi Nusa Tenggara Barat. Adapun waktu penelitian meliputi rentang waktu Februari sampai Agustus 2020. Populasi dalam penelitian ini adalah mahasiswa Universitas Gunung Rinjani angkatan 2017/2018 yang telah menempuh mata kuliah kewirausahaan berjumlah 279 orang. Penentuan sampel menggunakan rumus Slovin. Sumber data dalam penelitian adalah sumber data primer. Dalam penelitian ini peneliti menggunakan teknik pengumpulan data berupa kuesioner yang diberikan kepada masing-masing mahasiswa sebagai responden untuk diminta diisi dan dijawab (ditanggapi).

\section{HASIL DAN PEMBAHASAN}

Berikut ini adalah hasil dari kuisioner mengenai 12 ciri-ciri wirausaha menurut Anggadiredja dan Djajamiharja untuk mengetahui seberapa besar potensi ciri-ciri wirausaha yang dimiliki oleh responden.

Tabel 1 : Deskripsi Data Hasil Penilaian Potensi Ciri-ciri Wirausaha Menurut Anggadiredja dan Djajamihardja

\begin{tabular}{cccccc}
$\begin{array}{c}\text { Ciri } \\
\text { Wirausaha }\end{array}$ & $\begin{array}{c}\text { Jumlah } \\
\text { Responden }\end{array}$ & Maksimum & Minimum & Mean & Kategori \\
\hline Ciri 1 & 150 & 34 & 19 & 24.7 & SEDANG \\
\hline Ciri 2 & 150 & 32 & 16 & 24.6 & SEDANG \\
\hline Ciri 3 & 150 & 33 & 17 & 24.7 & SEDANG \\
\hline Ciri 4 & 150 & 40 & 19 & 25.4 & SEDANG \\
\hline Ciri 5 & 150 & 35 & 17 & 25.37 & SEDANG \\
\hline Ciri 6 & 150 & 33 & 18 & 25.5 & SEDANG \\
\hline Ciri 7 & 150 & 35 & 17 & 24.75 & SEDANG \\
\hline Ciri 8 & 150 & 36 & 15 & 24.6 & SEDANG \\
\hline Ciri 9 & 150 & 32 & 19 & 24.2 & SEDANG \\
\hline Ciri 10 & 150 & 30 & 18 & 24.45 & SEDANG \\
\hline Ciri 1 & 150 & 34 & 19 & 25.1 & SEDANG \\
\hline Ciri 12 & 150 & 35 & 17 & 25.1 & SEDANG \\
\hline Ket & & & & &
\end{tabular}

Keterangan :

$8-16=$ Rendah $\quad 17-31=$ Sedang $\quad 32-40=$ Tinggi

Sumber : Anggadiredja dan Djajamihardja, 1991 
Berdasarkan tabel diatas dapat dilihat bahwa nilai rata-rata masing-masing responden untuk 12 ciri yang dikemukakan oleh Anggadiredja dan djajamihardja adalah berada diantara rentang nilai 17-31 yang berarti potensi yang dimiliki berada pada tingkat sedang. Berikut hasil dari kuisioner mengenai 12 ciri-ciri wirausaha menurut Anggadiredja dan Djajamiharja untuk mengetahui seberapa besar potensi ciri-ciri wirausaha yang dimiliki oleh responden.

1. Mempunyai Emosi untuk Membayangkan Keberhasilan atau Takut akan Kegagalan

Dari hasil kuisioner rata-rata total nilai yang diperoleh adalah 24,7 sehingga termasuk kategori sedang

2. Berani Menanggung Risiko

Dari hasil kuisioner yang sudah ditanggapi oleh responden, rata-rata total nilai yang diperoleh adalah 24,6 sehingga termasuk kategori sedang.

\section{Gigih dan Bekerja Keras}

Dari hasil kuisioner yang sudah ditanggapi oleh responden, rata-rata total nilai yang diperoleh adalah 24,7 sehingga termasuk kategori sedang.

4. Semangat dan Gesit (Mobile)

Dari hasil kuisioner yang sudah ditanggapi oleh responden, rata-rata total nilai yang diperoleh adalah 25,4 sehingga termasuk kategori sedang.

\section{Memerlukan Umpan Balik}

Dari hasil kuisioner yang sudah ditanggapi oleh responden, rata-rata total nilai yang diperoleh adalah 25,37 sehingga termasuk kategori sedang.

6. Bertanggungjawab Secara Pribadi atas Perbuatan-perbuatan dan Keputusannya.

Dari hasil kuisioner yang sudah ditanggapi oleh responden, rata-rata total nilai yang diperoleh adalah 25,5 sehingga termasuk kategori sedang.

7. Percaya pada Dirinya Sendiri

Dari hasil kuisioner yang sudah ditanggapi oleh responden, rata-rata total nilai yang diperoleh adalah 24,75 sehingga termasuk kategori sedang.

8. Mempunyai Pengetahuan Luas 
Dari hasil kuisioner yang sudah ditanggapi oleh responden, rata-rata total nilai yang diperoleh adalah 24,6 sehingga termasuk kategori sedang.

9. Kemampuan Untuk Menghimbau

Dari hasil kuisioner yang sudah ditanggapi oleh responden, rata-rata total nilai yang diperoleh adalah 24,2 sehingga termasuk kategori sedang.

\section{Kecakapan Memimpin}

Dari hasil kuisioner yang sudah ditanggapi oleh responden, rata-rata total nilai yang diperoleh adalah 24,45 sehingga termasuk kategori sedang.

\section{Pembaharu (Inovator)}

Dari hasil kuisioner yang sudah ditanggapi oleh responden, rata-rata total nilai yang diperoleh adalah 25,1 sehingga termasuk kategori sedang.

\section{Memburu Keberhasilan}

Dari hasil kuisioner yang sudah ditanggapi oleh responden, rata-rata total nilai yang diperoleh adalah 25,1 sehingga termasuk kategori sedang.

Dengan demikian, berdasarkan hasil kuisioner secara keseluruhan diperoleh rata-rata total nilai dari 150 responden adalah berkisar antara 17-31 yang artinya berada pada kategori sedang. Memahami kemampuan diri dalam rangka pengembangan diri selaku seorang wirausahawan yang potensial, maka sangat penting sekali untuk mengidentifikasi siapa diri kita yang sesungguhnya serta bagaimana orang lain memperhitungkan diri kita (Suryana, 2011). Untuk memperkirakan diri sendiri, proses dini yakni kita wajib mengenali kelemahan yang terdapat dalam diri kita serta memperbaikinya, yang kedua yakni mengidentifikasi kemampuan apa yang ada dalam diri kita yang berikutnya kita ubah menjadi suatu kompetensi yang dibungkus dengan attitude yang baik, setelah itu kita dapat mencapai apa yang kita mau (kesuksesan).

\section{KESIMPULAN}

Berdasarkan hasil kuisioner dari 150 orang responden, diperoleh nilai ratarata untuk ciri pertama yaitu sebesar 24,7, ciri kedua nilai rata-ratanya yaitu 24,6, ciri ketiga nilai rata-ratanya 24,7, ciri keempat nilai rata-rata diperoleh sebesar 25,4, ciri kelima nilai rata-ratanya 25,37, ciri keenam nilai rata-rata sebesar 25,5 , ciri 
ketujuh diperoleh nilai rata-rata 24,75, ciri kedelapan diperoleh nilai rata-rata 24,6, ciri kesembilan nilai rata-ratanya 24,2 , ciri kesepuluh nilai rata-ratanya 24,45 , ciri kesebelas nilai rata-ratanya 25,1 dan ciri kedua belas nilai rata-ratanya sebsar 25,1. Sehingga demikian dapat disimpulkan bahwa potensi ciri-ciri wirausaha yang dimiliki masing-masing responden berada pada kategori sedang karena memiliki rentang nilai antara 17-31.

Memahami kemampuan diri dalam rangka meningkatkan diri sebagai seseorang wirausahawan yang potensial, maka perlu mengidentifikasi siapa diri kita sesungguhnya serta bagaimana orang lain memperhitungkan diri kita (Suryana, 2011). Dalam rangka mengembangkan diri sebagai seorang wirausahawan yang potensial, seseorang perlu mengenal potensi diri sendiri atau orang lain untuk dapat mengetahui apakah seseorang itu siap atau belum dalam melakukan wiraswasta suatu jenis usaha tertentu. Model Anggadiredja dan Djajamihardja merupakan suatu model untuk mengetahui ciri-ciri apa saja yang belum dimiliki secara memuaskan agar dapat diupayakan atau diperbaiki.

\section{DAFTAR RUJUKAN}

D. Anggadiredja, D. dan D. (1991). Ciri-ciri Kewiraswastaan. Lembaga Pengembangan Perbankan Indonesia.

Harfandi. (2014). Menggali Potensi Jiwa Kewirausahaan Mahasiswa PTAIN di Sumatera Barat. Jurnal Al-'Adl, 7(2), 125-144. https://doi.org/10.1017/CBO9781107415324.004

Kompas. (2016). Kenapa Lulusan Perguruan Tinggi Susah Mendapat Pekerjaan. https://edukasi.kompas.com/read/2016/04/23/17424071/Kenapa.Lulusan.Per guruan.Tinggi.Makin.Susah.Mendapat.Pekerjaan.?page=all.

Rumijati, A. (2010). Pengaruh Bakat Potensi Kewirausahaan dan Metode Pembelajaran Terhadap Minat Berwirausaha Mahasiswa. Ekonomika-Bisnis, 1(2), 187-200.

Satrya, I. B. H. dan I. G. M. S. (2015). Potensi Kewirausahaan Mahasiswa di Fakultas Ekonomi dan Bisnis Universitas Udayana. E-Jurnal Manajemen Unud, 4, 4559-4594.

Sugiyono. (2012). Metode Penelitian Kuantitatif, Kualitatif dan R\&D. Alfabeta. 
Inayati, Ihwandi.. Identifikasi Potensi Ciri-Ciri Wirausaha Dengan Model Anggadiredja Dan Djajamihardja Pada Mahasiswa Universitas Gunung Rinjani

Suryana, Y. dan K. B. (2011). Kewirausahaan Pendekatan Karaktersitik Wirausahawan Sukses (1st ed.). Kencana Prenada Media grup.

Suwena, K. R. (2015). Sebagai Pondasi Untuk Mensukseskan Program Mahasiswa Wirausaha ( Pmw ). Ilmu Sosial Dan Huaniora, 4(2), 651-660. 